\title{
IN VITRO CAPACITATION OF GOLDEN HAMSTER SPERMATOZOA WITH FALLOPIAN TUBE FLUID OF THE MOUSE AND RAT
}

\author{
C. BARROS* \\ Tulane University, Delta Regional Primate Research Center, \\ Covington, Louisiana, U.S.A.
}

(Received 24th April 1968)

The need for spermatozoa to undergo a physiological change in the female genital tract before they can penetrate ova was described by Austin (1951, 1952) and Chang (1951, 1955).

It has been demonstrated that rabbit spermatozoa survive for as long as $48 \mathrm{hr}$ in the uterus of an oestrous rat. Incubation of rabbit spermatozoa for different lengths of time in the rat uterus resulted in the fertilization of a high proportion of rabbit ova when the spermatozoa were injected into the Fallopian tube 12 to $13 \mathrm{hr}$ after an ovulation-inducing injection of gonadotrophins (Bedford \& Shalkovsky, 1967; Hamner \& Sojka, 1967). However, if spermatozoa were injected 14 to $14 \frac{1}{2} \mathrm{hr}$ after the gonadotrophins, practically no ova were fertilized (Bedford \& Shalkovsky, 1967). An inference was that only partial capacitation of rabbit spermatozoa had taken place in the rat uterus.

The idea that hamster spermatozoa can be capacitated in vitro was inferred from the finding that hamster ova were fertilized in vitro with epididymal spermatozoa (Yanagimachi \& Chang, 1964; Yanagimachi, 1966; Barros \& Austin, 1967). Observations by Barros (1968) clearly showed that the delay between semination and sperm penetration was due to the need for capacitation, since the prior incubation of hamster spermatozoa in tubal fluid containing ova in cumulus for $4 \mathrm{hr}$ reduced the delay from $3 \mathrm{hr}$ to nearly zero. By $2 \mathrm{hr}$ after semination, a large percentage of ova had extruded the second polar body and displayed pronuclei.

The technique of in vitro fertilization permits a study of the species-specificity of capacitation. The present paper reports data on the capacitation of hamster epididymal spermatozoa in vitro in the contents of mouse and rat Fallopian tubes.

Immature hamsters, mature mice and immature rats were treated with ovulation-inducing gonadotrophins. The contents of the Fallopian tubes were obtained under liquid paraffin and an equal volume of $0 \cdot 15 \mathrm{M}$-sodium chloride solution was added.

The distal part of the cauda epididymidis from adult male hamsters was dissected out, and small cuts were made on its surface; it was then placed

* Present address: Departamento de Biologia, Escuela de Medicina, Universidad Catolica de Chile, Santiago, Chile. 
under liquid paraffin, and $0.2 \mathrm{ml}$ of $0.15 \mathrm{M}$-sodium chloride solution was added to the spermatozoa. From this preparation about 3 to $5 \mu \mathrm{l}$ of sperm suspension were added to the tubal contents. Hamster spermatozoa were incubated in: (a) mouse tubal fluid containing ova in cumulus for $4 \mathrm{hr}$, and (b) rat tubal fluid containing ova, for 4 and $5 \mathrm{hr}$ at 36 to $37^{\circ} \mathrm{C}$. At the end of this period, the ova were transferred to another dish and freshly ovulated hamster ova added to the sperm suspensions. The mixture was incubated for an additional $2 \mathrm{hr}$ and, at the end of the second incubation period, ova were examined for the incidence of fertilization with a phase-contrast microscope. The mouse and rat ova removed from the first preparations were left in contact with hamster spermatozoa for 8 to $10 \mathrm{hr}$ to determine the possibility of cross-fertilization. In another experiment, hamster ova were washed (by transferring them successively to three fresh aliquots of $0.15 \mathrm{~m}$ sodium chloride solution), before semination with spermatozoa incubated in mouse and rat tubal fluids.

\section{TABLE 1}

In vitro FERTILIZATION OF HAMSTER EGGS WITH SPERMATOZOA PRE-INGUBATED in vitro WITH THE FLUID FROM THE FALLOPIAN TUBE OF THE MOUSE AND RAT

\begin{tabular}{|c|c|c|c|c|c|c|c|}
\hline \multicolumn{3}{|c|}{ Hamster spermatozoa incubated in: } & \multicolumn{5}{|c|}{ Semination of hamster ova } \\
\hline \multirow[b]{2}{*}{ Species } & \multirow{2}{*}{$\begin{array}{l}\text { No. of } \\
\text { females }\end{array}$} & \multirow{2}{*}{$\begin{array}{c}\text { Time } \\
(h r)\end{array}$} & \multirow{2}{*}{$\begin{array}{l}\text { Treatment } \\
\text { of ova }\end{array}$} & \multirow{2}{*}{$\begin{array}{c}\text { No. of } \\
\text { females }\end{array}$} & \multirow{2}{*}{$\begin{array}{c}\text { No. of } \\
\text { seminated } \\
\text { ova }\end{array}$} & \multicolumn{2}{|c|}{ Ova undergoing fertilization } \\
\hline & & & & & & Total & $\%$ \\
\hline $\begin{array}{l}\text { Mouse } \\
\text { Mouse } \\
\text { Mouse } \\
\text { Rat } \\
\text { Rat } \\
\text { Rat } \\
\text { Saline } \\
\text { suspension }\end{array}$ & $\begin{array}{r}4 \\
13 \\
10 \\
4 \\
8 \\
10 \\
-\end{array}$ & $\begin{array}{l}4 \\
5 \\
5 \\
4 \\
5 \\
5 \\
5\end{array}$ & $\begin{array}{l}\text { None } \\
\text { None } \\
\text { Washed } \\
\text { None } \\
\text { None } \\
\text { Washed } \\
\text { None }\end{array}$ & $\begin{array}{l}3 \\
5 \\
8 \\
3 \\
6 \\
8\end{array}$ & $\begin{array}{r}56 \\
128 \\
115 \\
80 \\
213 \\
101\end{array}$ & $\begin{array}{r}1 \\
29 \\
15 \\
7 \\
111 \\
50\end{array}$ & $\begin{array}{r}1 \cdot 8 \\
22 \cdot 0 \\
10 \cdot 7 \\
8 \cdot 7 \\
52 \cdot 0 \\
50 \cdot 0\end{array}$ \\
\hline
\end{tabular}

The results (Table 1) show that, when hamster spermatozoa were incubated for $4 \mathrm{hr}$ in either mouse or rat Fallopian tube contents, the proportions of penetrated hamster ova were 1.8 and $8.7 \%$, respectively; however, when spermatozoa were incubated for $5 \mathrm{hr}$ the proportions of penetrated hamster ova were 22 and $52 \%$, respectively. The data also showed that washing of hamster ova before semination did not greatly reduce the incidence of fertilization. In a control experiment none of 127 ova was penetrated $2 \mathrm{hr}$ after semination with spermatozoa pre-incubated for $5 \mathrm{hr}$ in $0.15 \mathrm{M}$-sodium chloride solution.

The mouse and rat ova became denuded of cumulus and corona cells, and a large number of spermatozoa were attached to the zona; some free acrosomes were also seen attached to the zona.

None of 280 mouse ova was penetrated by hamster spermatozoa, but one rat ovum (Pl. 1, Figs. 1 and 2) of 294 ova contained hamster spermatozoa in the perivitelline space. This ovum was carefully examined for a rupture of the zona pellucida, but none was found. Dickmann (1962) has also recorded an interspecific sperm penetration: a rabbit spermatozoon in a rat egg. 

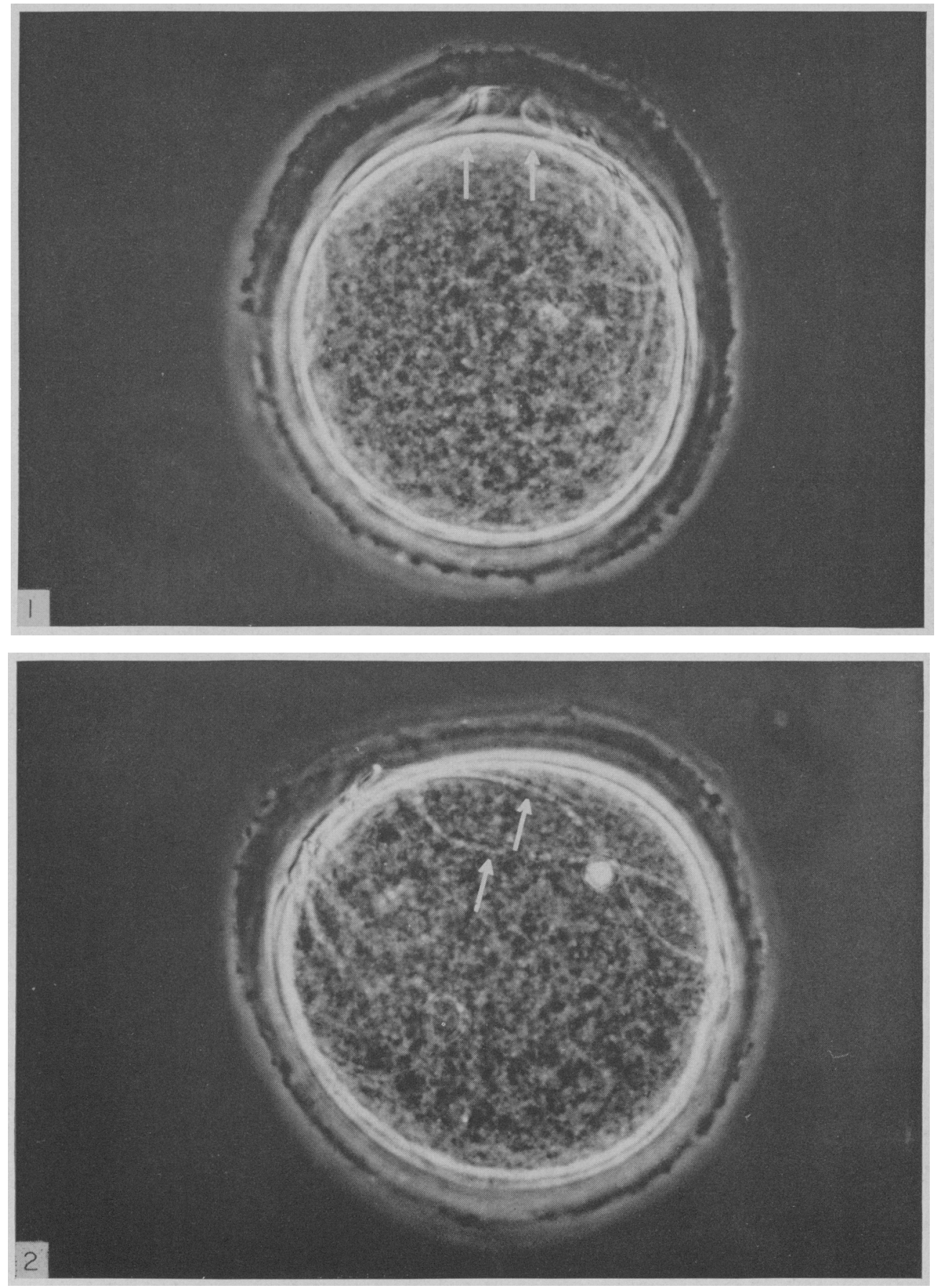

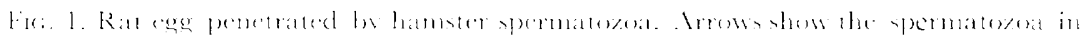

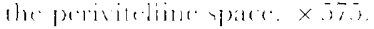

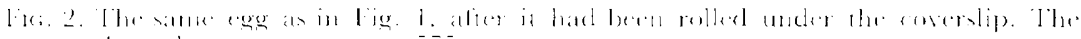

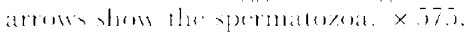

Fritime (1. 201 
The results herein reported agree with a previous finding in which it was found that mouse and rat tubal fluid had the effect of eliciting the acrosome reaction in hamster spermatozoa (Barros \& Austin, 1967); furthermore, sperm penetration took place at times earlier than $3 \mathrm{hr}$, which would indicate that hamster spermatozoa were indeed capacitated in vitro in fluids from foreign species.

The presence of an agent or of agents that support capacitation in vitro has been demonstrated in the Fallopian tube of the golden hamster (Barros \& Austin, 1967). Results of the present study show that even after washing the eggs the percentage of fertilization was still high, when the spermatozoa had been incubated in fluids from the Fallopian tubes of mice and rats. These findings support the idea that hamster spermatozoa can achieve an advanced state of functional capacitation with fluids of a foreign species, though participation of hamster secretions in the later stages of capacitation cannot be absolutely excluded.

Two tentative hypotheses can be advanced to explain the relationship between time of incubation of spermatozoa and stage of capacitation achieved: (1) the active agent found in the mouse and rat is not identical with that found in the hamster and is less effective in inducing capacitation; or (2) the agent is the same but is present in smaller amounts. In either case it would require a longer time to exert its effect.

The presence in the acrosome of a 'zona lysin' was postulated by Austin \& Bishop (1958), and a preparation from acrosomes has been found to contain a substance that will digest the zona pellucida (Srivastava, Adams \& Hartree, 1965). Chang \& Hunt's (1956) observations on enzyme digestion suggest differences in constitution of the zona of hamster, rat and rabbit ova. This evidence, and the fact that hamster spermatozoa are rarely able to penetrate mouse and rat ova, would confirm the finding that there are species differences in the zona. In addition, there are presumably species differences in the properties of the 'zona lysin' present in the acrosomes.

I am indebted to Professor C. R. Austin for his interest and advice during the course of this work and also for reading and commenting on the manuscript.

This work was supported by Public Health Service Grants FR 00164 and GM 32216 from the National Institutes of Health.

\section{REFERENCES}

Austin, C. R. (1951) Observations on the penetration of the sperm into the mammalian egg. Aust. $\mathcal{F}$. scient. Res. B, 4, 581 .

Austin, C. R. (1952) The 'capacitation' of the mammalian sperm. Nature, Lond. 170, 326.

Austin, C. R. \& Bishop, M. W. H. (1958) Role of the rodent acrosome and perforatorium in mammalian spermatozoa. Proc. R. Soc. B, 149, 241.

BARros, C. (1968) Capacitation in vitro of golden hamster spermatozoa. Anat. Rec. 160, 310.

Barros, C. \& Austin, C. R. (1967) In vitro fertilization and the sperm acrosome reaction in the hamster. J. exp. Zool. 166, 317.

Bedford, J. M. \& Shalkovsky, R. (1967) Species-specificity of sperm capacitation in the rabbit. 7. Reprod. Fert. 13, 361.

Chang, M. C. (1951) Fertilizing capacity of spermatozoa deposited into the fallopian tubes. Nature, Lond. 168, 697. 
Chang, M. C. (1955) Development of fertilizing capacity of rabbit spermatozoa in the uterus. Nature, Lond. 175, 1036.

Chang, M. C. \& Hunt, O. M. (1956) Effects of proteolytic enzymes on the zona pellucida of fertilized and unfertilized mammalian eggs. Expl Cell Res. 11, 497.

Dickmann, Z. (1962) Experiments on interspecific sperm penetration through the zona pellucida. J. Reprod. Fert. 4, 121.

Hamner, C. E. \& SojKA, N. J. (1967) Capacitation of rabbit spermatozoa : species and organ specificity. Proc. Soc. exp. Biol. Med. 124, 689.

Srivastava, P. N., Adams, C. E. \& Hartree, E. F. (1965) Enzymic action of acrosomal preparations on the rabbit ovum in vitro. $\mathcal{F}$. Reprod. Fert. 10, 61.

Yanagmachi, R. (1966) Time and process of sperm penetration into hamster ova in vivo and in vitro. J. Reprod. Fert. 11, 359.

Yanacmachi, R. \& Chang, M. C. (1964) In vitro fertilization of golden hamster ova. F. exp. Zool. 156, 361 . 